\title{
Extraversion, neuroticism and the classical conditioning of word meaning
}

The connotative meaning of words was established by classical conditioning procedures. In the line with the prediction from Eysenck's theory, introverts showed a greater degree of conditioning than extraverts. The prediction from Spence's theory that Ss scoring high on a neuroticism scale would condition more readily than those scoring low was not confirmed.

Staats and Staats and their associates have shown in a number of investigations (e.g., Staats, Staats, \& Heard, 1961; Staats, Staats, Heard, \& Nims, 1959; Staats \& Staats, 1957) that when a group of words having a common connotative meaning are each paired once as a UCS with a nonsense syllable CS, the connotative meaning of the nonsense syllable becomes more like the meaning of the UCS words, as measured by semantic differential ratings (Osgood \& Suci, 1955). Their evidence has been used to support the concept of word meaning as an implicit mediating response as suggested by Mowrer (1954), Osgood (1953), and Staats (1961).

The two main personality variables that have been related to conditioning are extraversion and emotionality. Eysenck (1957) has proposed the hypothesis that conditioning would correlate with introversion and has recently reviewed the evidence in relation to the hypothesis (Eysenck, 1965). Spence \& Taylor (1951) proposed that conditionability would be positively correlated with anxiety, and Spence (1964) has recently reviewed the experimental work relating to this hypothesis.

The present study was designed to investigate the relationship between these personality variables and the clinical conditioning of connotative meaning.

In view of the high correlations (e.g., Franks, 1956; Bendig, 1960) between Taylor Manifest Anxiety Scales Scores (Taylor, 1953) and scores on the Neuroticism (N) scale of the Maudsley Personality Inventory (MPI) (Eysenck, 1962) the latter scale was used to test the prediction from Spence's theory that Ss with high levels of emotionality (high $\mathrm{N}$ scores) would be conditioned more readily than those with low levels of emotionality. The prediction from Eysenck's theory was that introverted Ss would be more readily conditioned than extraverted Ss.

\section{Method}

Two weeks prior to the conditioning session the MPI was administered to 180 students in an introductory psychology class. From these $180 \mathrm{Ss}, 40 \mathrm{Ss}$ were selected on the basis of their scores on the $\mathrm{N}$ and $\mathrm{E}$ scales. Ten Ss were selected to form the extra- verted group (mean E score $=39.5$ ) and 10 were selected to form the introverted group (mean $E$ score $=8.5$ ). The Ss were selected so that they did not differ significantly in scores on the $\mathrm{N}$ scale (extraverts mean $\mathrm{N}$ score $=19.7$; introverts mean $\mathrm{N}$ score $=23.0$ ).

Ten Ss were selected to form the high neuroticism group (mean $N$ score $=38.2$ ), and 10 were selected to form the low neuroticism group (mean $\mathrm{N}$ score $=$ 5.2). The mean extraversion scores for the two groups did not differ significantly (high neuroticism group mean $E$ score $=27.5$; low neuroticism group mean $E$ score $=33.0$ ).

The 40 selected $\mathrm{Ss}$ were tested as a group; all stimuli were presented on a screen. In order to orient them to the conditioning phase of the experiment, two learning tasks were presented. The first task consisted of learning as many as possible of five words each presented on the screen four times in random order. The second task consisted of learning as many as possible of 30 words each presented orally once.

The Ss were then told that the purpose of the next part of the experiment was to see how learning could be facllitated with a combination of oral and visual presentations. Four words were used as visually presented CSs: wet, thick, long, and wide. The following words were used as buffer items: yellow, deep, strong, tidy, due. The words wet and thick were found by Osgood \& Suci (1957) to be neutral in relation to their "evaluation" factor (factor loadings were: wet, 0.08 and thick, 0.06). They also found that the words long and wide were neutral in relation to the "activity" factor (factor loadings were: long, 0.03, wide, 0.07).

The 10 words were presented visually in random order each with exposures of $5 \mathrm{sec}$ and each being presented 18 times. The $\mathrm{E}$ sitting at the back of the room pronounced a UCS word $1 \mathrm{sec}$ after each of these 10 words were presented on the screen. Each of the 10 visually presented words was paired with a different UCS word for each presentation.

The word wet was paired with words having a positive evaluative connotation, namely: good, sacred, happy, tasty, joyful, beneficial, sweet, valuable, kind, nice, affectionate, pleasant, delightful, honest, fragrant, beautiful, considerate, and clean.

The word thick was paired with words having a negative evaluative meaning, namely: profane, dishonest, harmful, bitter, sad, awful, bad, unpleasant, foul, displeasing, cruel, ugly, worthless, hateful, grievous, dirty, sour, and distasteful.

The word wide was paired with words having a pas- 
sive connotation, namely: dull, slow, idle, still, inert, bleak, cautious, blunt, cold, passive, rounded, calm, leisurely, icy, relaxed, unhurried, quietly, and freezing.

The word long was paired with words having an active connotation, namely: fast, sharp, lively, excitable, burning, angular, hot, tense, steaming, rash, breathless, energetic, boiling, active, hasty, moving, keen, and scrambling.

Immediately following the conditioning phase of the experiment, Ss rated the 10 visually presented words on the evaluative and activity scales of the Semantic Differential. On questioning Ss individually, it was found that none of the Ss had been aware of the true purpose of the experiment.

For each $S$ the difference in the evaluative ratings of the words wet and thick were taken to indicate the degree to which these words had acquired the evaluative connotations of the UCS words with which they had been paired. The difference in the activity ratings of the words wide and long were taken to indicate for each $S$ the degree to which these words had acquired the activity connotations of the UCS words. These difference scores were combined for each $S$ to give an overall measure of degree of conditioning.

\section{Resulis and Discussion}

When $t$ tests were used to assess the significance of the mean scores for the selected group of Ss, it was found that the scores for introverts differed significantly from those of extraverts $(t=2.141, \mathrm{df}=18$, $p<.05)$. The mean difference of the evaluative and activity ratings of words conditioned to opposite ends of these dimensions was 0.01 for extraverts and 1.66 for introverts.

The difference in scores for those Ss scoring either high or low on the neuroticism scale was not statistically significant.

These findings suggest that Eysenck's rather than Spence's theory will be more successful in predicting individual differences in the ease with which the connotative meaning of words will be conditioned.

\section{References}

Bendig, A. W. Factor analysis of "anxiety" and "neuroticism" inventories. $J$. consult. Psychol., 1960, 24, 161-168.

Eysenck, H. J. The dynamics of anxiety and hysteria. New York: Praeger, 1957.

Eysenck, H. J. The Maudsley Persomality Inventory. San Diego. Educational and Industrial Testing Service, 1962.

Eysenck, H. 3. Extraversion and the acquisition of eyeblink and GSR conditioned responses. Psychol. Bull., 1965, 63, 258-270.

Franks, C. M. Conditioning and personality. J. abnorm. soc. Psychol., 1956, 52, 143-150.

Mowrer, O. H. The psychologist looks at language. Amer. Psychol., $1954,9,660-694$.

Osgood, C. E. Method and theory in experimental psychology. New York: Oxford University Press, 1953.

Osgood, C. E., \& Suci, G. J. Factor analysis of meaning. J. exp. Psychol., 1955, 50, 325-338.

Spence, $\mathbf{K}$. W. Anxiety (drive) level and performance in eyelid conditioning. Psychol. Bull., 1964, 61, 129-139.

Spence, K. W., \& Taylor, J. A. Anxiety and strength of UCS as as determinants of amount of eyelid conditioning. J. exp. Psychol., 1951, 42, 183-188.

Staats, A. W. Verbal habit-families, concepts, and the operant conditioning of word classes. Psychol. Rev., 1961, 68, 190-204.

Staats, C. K., \& Staats, A. W. Meaning established by classical conditioning. J. exp. Psychol., 1957, 54, 74-80.

Staats, A. W., Staats, C. K., \& Heard, W. G. Denotative meaning established by classical conditioning. J. exp. Psychol., 1961, 61, 300-303.

Staats, A. W., Staats, C. K., Heard, W. G., \& Nims, L. P. Replication reports: Meaning established by classical conditioning. $J$. exp. Psychol., 1959, 57, 64.

Taylor, F. A. A personality scale of manifest anxiety, J. abnorm. soc. Psychol., 1953, 48, 285-290. 